\title{
DEFINING THE REQUIREMENTS FOR A TOOL TO SUPPORT CIRCULAR ECONOMY BUSINESS MODEL INNOVATION WITHIN MANUFACTURING COMPANIES - CORRIGENDUM
}

\author{
M. P. P. Pieroni ${ }^{凶}$, T. C. McAloone and D. C. A. Pigosso \\ DTU-Technical University of Denmark, Denmark \\ $\triangle$ mdpp@dtu.dk
}

doi: https://doi.org/10.1017/dsd.2020.28. Published by Cambridge University Press, 11 June 2020.

An incorrect title for the aforementioned article was published, this has since been rectified. The authors apologise for this error.

\section{Reference}

Pieroni, M.P.P., McAloone, T.C. and Pigosso, D.C.A. (2020), "Defining the Requirements for a Tool to Support Circular Economy Business Model Innovation within Manufacturing Companies," in Proceedings of the Design Society: DESIGN Conference, Cambridge University Press, Vol. 1, pp. 2119-2128. https://doi.org/ 10.1017/dsd.2020.28 